\title{
A Voice Without a Name: Choruses and Storytellers in Ben Okri's The Famished Road
}

\section{Vanessa Guignery}

\section{(2) OpenEdition \\ 1 Journals}

Electronic version

URL: https://journals.openedition.org/ces/5359

DOI: $10.4000 /$ ces.5359

ISSN: 2534-6695

\section{Publisher}

SEPC (Société d'études des pays du Commonwealth)

\section{Printed version}

Date of publication: 1 April 2013

Number of pages: $79-89$

ISSN: 2270-0633

\section{Electronic reference}

Vanessa Guignery, "A Voice Without a Name: Choruses and Storytellers in Ben Okri's The Famished Road", Commonwealth Essays and Studies [Online], 35.2 | 2013, Online since 17 April 2021, connection on 23 July 2021. URL: http://journals.openedition.org/ces/5359; DOI: https://doi.org/10.4000/ces. 5359

\section{cc) (†) $\ominus$}

Commonwealth Essays and Studies is licensed under a Licence Creative Commons Attribution - Pas d'Utilisation Commerciale - Pas de Modification 4.0 International. 


\section{A Voice Without a Name: Choruses and Storytellers in Ben Okri's The Famished Road}

This paper proposes to explore the poetics of voice in Ben Okri's The Famished Road, a novel in which a myriad of individual and collective voices resonate without always being clearly identified. The study examines more specifically the duality of Azaro's voice, but also the novel's indebtedness to the indigenous tradition of oral folktales and its paradoxical celebration of orature in a text that is, by definition, silent.

In Ben Okri's The Famished Road, one of the riddles that "neither the living nor the dead can answer" (559) pertains to the often uncertain origin of voices that reverberate throughout the novel, be they individual or collective, enticing or frightening, airborne or ghostly, angry or lulling, hesitant or adamant. First amongst these is the homodiegetic narrator's dual voice, which is both that of a spirit-child with paradoxically both a limited and an exceptional understanding of his surroundings, and that of a more mature narrator given to philosophical and poetic utterances. In addition, the novel resonates with anonymous choruses of "voices without bodies" (196) or voices without a name. ${ }^{1}$ The lack of any clear identification of these collective voices, belonging either to the spirit realm or to the real world, raises questions as to their essence and function, as well as to the literary tradition within which the novel is inscribed, oscillating between realism and written literature on the one hand, and the fantastic and orature on the other hand. One may wonder how the writer manages to reconcile the demands of written narrative with the novel's indebtedness to the indigenous tradition of oral storytelling, folktales and myths conventionally told by the griot in West Africa and passed down through generations. This study will therefore examine the characteristics of the myriad of voices in The Famished Road - individual and collective -, their ambivalent identities and the paradoxical celebration of the tradition of orature in a written text that is, by definition, silent. In the process, we will try and determine whether Okri succeeds in allowing any specific and meaningful voice to emerge from what sometimes sounds like a cacophony or a "delirium of stories" (213).

"In the beginning there was a river" (3). The Famished Road opens with biblical and mythical overtones that situate the novel from the start within a religious, spiritual and etiological framework, without however identifying the origin of the voice that makes such a memorable and yet simple statement. The reader has to wait until the next paragraph to hear the first person plural pronoun resonate in an anaphoric, epiphoric and hyperbolic litany: "We could assume numerous forms. [...] We feasted much [...]. We played much $[\ldots]$. And we sorrowed much [...]" (3). For three pages, the individual narrative voice is hiding among this collective group of "spirit companions" (4) until the narration zooms in on the first person singular pronoun at the end of a paragraph via a brisk monosyllabic sentence: "So it was with me" (5). This sudden unveiling of the main subject (as grammatical object) is followed by a series of anaphoric questions: "How many times had I come and gone [...]? How many times had I been born and

1. In House of Leaves, Mark Z. Danielewski refers to "[a] voice without a name. As immortal as my life" (327). 
died young? And how often to the same parents? I had no idea" (5). This very original narrative voice, which has now been identified as that of an abiku or spirit-child, is presented from the start as lacking in knowledge and is thus far from being granted the usual abilities of an omniscient narrator. This rebellious abik $u$ who decides to break his pact with the spirits and remain in the mundane world is one who has only a partial comprehension of what is going on around him, probably because of his young age. At the same time, his voice often takes on the characteristics of an adult narrator, as in the very first sentence, for instance, but also in the gnomic, proverbial and philosophic statements that pepper the whole book, thus making it difficult to precisely situate the voice in time. In an interview, Okri admitted that " $[\mathrm{t}]$ he point of view of the telling and the teller is ambiguous" since the story is "not being told in the time of the person that you're reading about. That ambiguous distance complicates the vocabulary" (Guignery Homelands 20-1).

Ato Quayson analyses this dichotomy by pointing to "contradictions between the 'I' of the narrating instance and the 'I' of the narrated events," (125) that is between the voice of the narrator who tells the story after the facts (though the reader does not know exactly when), and that of the character who reacts in direct speech to his present experiences. In direct speech, Azaro often asks questions that reveal his limited understanding of some aspects of the world around him, as, for instance, when he asks Dad: "What is suicide?" (274) or when he asks the photographer a series of baffled questions after being confronted with the picture of "a man hanging by his neck from a tree" (304). The dialogue between the two reveals Azaro's dogged curiosity and desire to learn, and the photographer's enigmatic and self-conscious evasion of the truth:

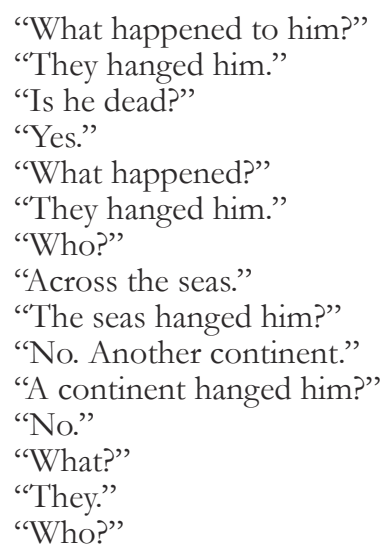

He paused. I was confused.

"Some white people."

I didn't understand. [...]

"Why?"

$[\ldots]$

"Why?"

"Why what?"

"Why did they hang him?"

He was silent. (304-5) 
This dialogue in stichomythia is representative of a great number of passages in direct speech in the novel and is emblematic of the type of simple and direct questions a child would ask (what? who? why?), and of Azaro's non-euphemistic use of words ("hang," "dead"). The adult character on the other hand, after a few blunt answers, becomes self-conscious and his elliptical replies cease to make sense, as Azaro's stubborn and literal questions and the rhetorical device of anadiplosis ${ }^{2}$ point out. The text seems to be stammering and heading towards blanks and silence via shorter and shorter lines as the photographer's monosyllabic cues and his repeated silences testify to his unease and to the difficulty of speaking the unspeakable and of reporting on traumatic experiences.

Even if the voice of the adult narrator is more informed than that of the child character, having the benefit of hindsight to reflect on his condition and the events that took place, and a mastery of language that lets him speak in poetic and philosophical tones, it still sometimes lets the focalisation of the baffled spirit-child prevail so that some scenes remain blurred and confusing, especially those in which choruses of anonymous voices and groups of indistinct noises can be heard. The anaphoric leitmotiv of "The air was full of cries," (11) "The air was full of noises" (446) or "The darkness was full of voices," (545) points to Azaro's attentiveness to impalpable impressions around him but also to his inability to identify the origin of these sounds. The first quote appears during the dreadful "night of fires" (11) when the compound is burning and the inhabitants are frantically trying to extinguish the fire that is devouring their ramshackle homes. The sentence recalls Vladimir's despairing words at the end of Samuel Beckett's Waiting for Godot (1956): "The air is full of our cries," (84) though in Beckett's text, the possessive pronoun clearly identifies the originators of the despondent wails and their angst as individuals. In Okri's novel, the inhabitants of the ghetto are an indistinct group, existing as a collective whole and not as separate entities. These "compound voices" (81) may resonate in the night but they are eventually muffled by the landlord and the police, and replaced by the "ancient war-songs" chanted by urban gangs, the "laughter of mischievous spirits," (12) the vibrating drums and the "funeral roar" of a gigantic and terrifying Masquerade which "ffilled the street with an ancient silence" (13). The spectral ("ancient") and anonymous voices of the past thus come back to haunt the compound, be they the "blue memories" $(210,208,213)$ of the violent history of the colonised country or the traces of the indigenous folklore that has retained its potency.

In this soundscape, the voices of the impoverished population of the ghetto mostly remain unheard, reduced to cries and then silenced. They belong to the dispossessed, the voiceless, the subaltern, "the wretched and the hungry and the homeless," (474) those who cannot speak for themselves and whom Okri's father, a lawyer, used to defend: "he took up the cases of slum dwellers who had nobody else to speak for them" (qtd. in Stenhouse 7). Okri himself developed a habit of writing about "people who are powerless, who are suffering, struggling, the voiceless, the silenced, who are unspoken for" (qtd. in Deandrea 57). In The Famished Road, Dad takes on the role of spokesman for the destitute and, more particularly, the community of beggars. But all these voices remain relatively indistinct, as suggested by the scarcity of names in the novel. Hardly any of the characters bears a proper name and most names are merely "typicalisations

2. Anadiplosis is a rhetorical figure in which the last word or phrase of one clause, sentence, or line is repeated at the beginning of the next. This is the case here of "seas" and "continent." 
or generalisations" (Elze-Volland 54). People are identified either through their family function (Dad, Mum), their profession (the carpenter, the photographer, the landlord) or a physical characteristic (the blind old man, the men in dark glasses). This enables the writer to provide a social panorama rather than specific realistic descriptions and individualized voices: characters are seen as types rather than individuals. Even Mum and Dad represent an everyman and an everywoman so much so that Azaro, at the market, is "confused by many voices that could have been Mum's, many faces that could have been hers" (190).

In addition, the ghetto-dwellers' voices are superseded by those of the figures of authority and of politicians who are crudely separated into two political parties, the Party of the Rich and the Party of the Poor. The names are so general and caricatural as to debunk any serious purpose the parties may have, and the politicians are never identified individually by their names, thus remaining an anonymous group. Sheltered in their vans, they communicate to the crowd through megaphones and are reduced to the status of impersonal and disembodied voices: "The voices urged us [...]. The voices told us [...]" (443). In Infinite Riches, the third volume of the trilogy, Azaro notes that the politicians act as if the voters did not exist, as if their voices were mute: "We, the crowd, were the ghosts of history. [...] We were shadows in the world of power; the mere spectators of phenomena, the victims of speeches. We were meant only to listen, never to speak" (262-3).

The powerless and the voiceless are thus confined to the sidelines of the building of the new nation, and the distribution of speech (and silencing of the main population) reflects the apportionment of power. The second volley of noises alluded to earlier - "The air was full of noises" (446) 3 - is indeed that of politicians blaring music from their vans and "making their interminable announcements and promises" (446). The scene is a cacophonous one in which the true content of the political message is lost: "they competed with the amount of noise they could generate. They insulted one another in their contest of loudspeakers; and the heated blare of their music clashing created $[\ldots]$ a jangle in the air" (446). The competition and contest is one of noises and insults rather than ideas and arguments, thus confirming the lack of any genuine political debate and the interchangeability of the two parties.

When the politicians' speeches are transcribed (which is relatively rare, as though the political message per se was unimportant), they talk in catch phrases and clichés. For instance, when the Party of the Rich comes to the compound to distribute free powdered milk, the speech of the spokesman, a "magnified voice," (145) is rendered in capital letters while the throng's reaction, "mocking voices" at first (145), is reported in lower case, which not only reflects the different sound level of the voices but also points to the balance (or imbalance) of power between the two.

"IF YOU VOTE FOR US..."

“... we are finished," someone added.

3. These menacing urban noises contrast with the sweet airs of Caliban's island in The Tempest: "the isle is full of noises, / Sounds, and sweet airs, that give delight and hurt not" (III, 2, 133-4). 


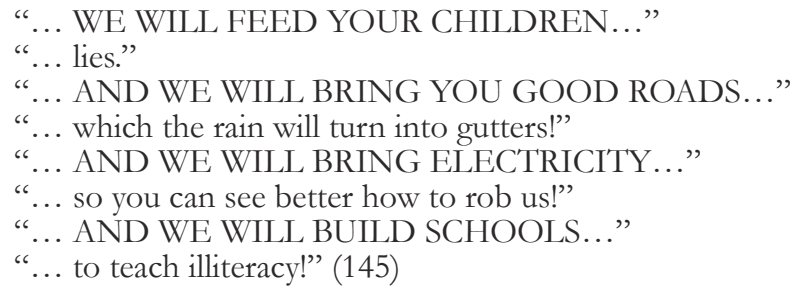

The distrustful anonymous voices of the crowd lampoon the stereotyped political discourse by systematically transforming the anaphorical electoral promises into negative forebodings. However, the capital letters dominate the page visually just as the sound of the loudspeaker eventually silences the sarcastic voices and breaks down the people's scepticism as free milk is being offered. The politicians' deception and hypocrisy are later exposed when they are heard promising "ELECTRICITY AND BAD ROADS, NOT GOOD MILK, I MEAN GOOD ROADS, NOT BAD MILK" (180). The crude chiasmus of the adjectives "good" and "bad" reveals how words have become empty signifiers, unrelated to any genuine political agenda.

Both the population of the ghetto and the politicians are thus presented as groups of voices rather than individual human beings, which tends to disincarnate and dehumanise the very construction of the new nation. Other everyday scenes are marked by a polyphony of voices that talk in stichomythia and fail to be precisely identified, probably because the child from whose perspective the episodes are viewed and heard is unable to recognize specific voices and sounds. ${ }^{4}$ Quite often, conversations start up with groups of people who comment on the situation at hand. For instance, both the compound people (323) and the prostitutes in the bar (338) discuss the new developments in Madame Koto's condition, a type of small talk that is based on very short sentences with repetitions and anaphoras, and is regularly interrupted by silence, similar to movements in a piece of music. In these rapid conversations, no indication is given as to who exactly is speaking, as people are granted an identity as a collective group and not as individuals. These dialogues are also ways of providing information about Madame Koto and her economic development through the perspective of common people, thus symbolising public opinion.

Other voices belonging to the esoteric realm or the real world likewise remain obscure. In the house of the policeman, for instance, Azaro notes: "There were voices everywhere," (25) voices that are not identified but seem to be those of the dead. The same sentence recurs later on when Azaro is at the market: "There were voices everywhere. There were movements and voices everywhere" (200); "there were many voices, loud and clashing voices" (190). A mysterious aura envelops these unidentified voices, linked to the fact that there are so many of them and that the reader is not told what they actually say. This is also the case when Mum and Azaro walk through the streets one day: "All around us voices were raised in laughter and in pain" (324) - they hear singing and chanting, but no indication is given as to the actual words: "the singing was full of secrets and dread-making voices" (324). The riddle persists and no dominant voice or message can emerge from the polyphony. At the marketplace when Azaro is looking for

4. The description of the night of wild jaguars (208-13), a ruthless confrontation between political thugs, the inhabitants of the compound and the dead risen from the earth, is marked by a great emphasis on sonorous effects. For a detailed analysis of this episode, see Guignery Seeing and Being, 128-32. 
his mother, the spirit-child is also confronted with a succession of voices that remain mysterious to him but seem connected with each other, testifying to the intricate intertwining of the mundane world and the esoteric one. ${ }^{5}$ After Azaro's encounter with the old man selling roots and herbs and his uncanny experience of a separation between body and spirit, he hears an odd combination of sounds:

The sounds of the marketplace took on a new quality. A million footfalls magnified on the earth. Voices of every kind rose in massive waves and distilled in whispers. From afar, I heard the muezzin calling. [...] Bells and angelic choirs sounded close to my ears and then would melt away. (194)

The sense of a polyphony is conveyed by the plural forms and the hyperbole of a "million footfalls," and seems to evolve in successive waves of crescendos ("magnified," "rose," "massive") and decrescendos ("distilled in whispers," "melt away"). The close sounding of the Muslim call to prayer and the Christian bells and choirs may suggest a harmonious coexistence of religious faiths. This scene that loudly resonates is followed by the sudden perception of "a voice, which seemed to come from nowhere, and which was not the voice of a spirit" (195). This voice, which is only identified negatively ("nowhere," "not"), is a full agent as it is the grammatical subject of the sentence ("a voice [...] said" [195]) or else is hidden behind the passive form ("the question was asked" [195]), which enables the narrator not to name the speaker. The dialogue is in stichomythia and the voice asks Azaro a series of brief and simple questions such as "Where is the old man?", "Where did he run to?", "What direction?", "Who is your mother?", "Why are you looking for her?", and eventually "What is your name?" (195), a final question that is asked three times and whose answer is not transcribed in direct speech. Interestingly enough, the old man had previously asked Azaro the same questions: "Who is your mother?" "Why are you looking for her?", "What is your name?" (192-3). The similarity of questions asked by the two personae may suggest that they belong to the same world, though which world that would be remains mysterious since Azaro said the second voice, despite not being attached to any specific person, was not that of a spirit. Just as the old man suddenly dissolved, the voice's abrupt disappearance is poetically signalled by Azaro's head hitting "the hardness of silence" (195) and the world being plunged into darkness, an auditory and visual blackout emblematic of the young child's confusion and position, hovering "in the interspace" (5) between the supernatural and the worldly.

Soon enough however, a choir of new voices can be heard: "From the moon [...] I heard other voices, full of darkness" (195). These "voices without bodies," "turning on themselves, as in a numinous ritual" follow Azaro as he is "lifted up by the darkness, pushed on by invisible hands" (196). These indications and the lexical field ("without bodies," "numinous," "invisible") all seem to point towards a manifestation of the spiritual world, though the mysterious voices are also discussing earthly matters, such as independence and the future of the country. The two short passages in direct speech (195-7) are less a dialogue than a quick succession of brief statements of just a few words, structured around leitmotivs (or refrains) which frame the discussions: "Look at

5. As Christopher Warnes remarks, "[i]n traditional Yoruba culture, the marketplace is a space where spirit and real worlds meet" (140).

6. In Infinite Riches, as Azaro is running through a blossoming world of shadows, mirrors and dreams, he can also hear "[v]oices without bodies" (306). 
him" opens and ends the first part, "Maybe he's not well" the second part. The voices that make hypotheses as to Azaro's situation take on the function of a Greek chorus that, in classical plays, commented with a collective voice on the dramatic action, communicated what a character could not say and gave insight into the various scenes. Greek choruses usually expressed themselves in the form of songs and in verse, which finds an equivalent here in the short and simple repetitive cues that sound like refrains. ${ }^{7}$ The anaphorical and symmetrical prophecies uttered by these voices (196), sounding like a litany, also recall one of the functions of oracular Greek choruses who could send warnings to characters or audiences. Just like the old man and the second voice, this choir drifts "away on the air," born by a "bright wind," (194, 197) while Azaro reconnects with solid earth. In the three successive appearances and dissolutions of voices, the recurrent presence of the wind seems to suggest that the voices, which take on a dreamlike quality, might only be heard by Azaro and thus belong to the esoteric world. Such an episode points to Azaro's special status as an in-between figure, hovering between two worlds and thus able to hear voices in both realms, be it that of a giant turtle in an example of prosopopeia (20) or indistinct and impalpable voices as, for example, when he escapes from the grip of albino men and finds that "the road became a river of voices" (132).

Among this cacophony of collective voices, some individual voices do emerge and prevail as one of Azaro's gifts consists in being able to hear simultaneously the voice of a spirit and that of a member of his family or the community, which sometimes implies a competition between the mundane world and the esoteric realm to capture Azaro's attention and keep him in their respective spheres. This oscillation also reflects the literary hesitation within the book between the realist tradition inherited from the West, epitomised by the strenuous life in the compound, and the indigenous folk tales populated by supernatural creatures. The most blatant example of Azaro's alertness to voices from the two worlds occurs when the young child refuses to eat for several days to protest against his father flogging him. After a while Azaro begins to synaesthetically smell the world of spirits, see "the fields of music," listen to "the music of famine" and "the unsung melodies of spirit companions," and sing "the songs of departures" (374). As they are walking along a mighty green road on their way back to the esoteric world, the young boy and the three-headed spirit talk with each other, "the spirit's voice" reverberating (387), while at the same time his desperate parents in their run-down singleroom home are pleading with him not to die (380), his mother "speaking good words [...] in the voice of the wind," (383) his father talking to him "gently" (386) about his love for him in poetic and proverbial monologues. When Dad falls silent, Azaro remarks: "I wanted him to carry on speaking. His words offered me water and food and new breathing" (386). Just as he mentioned earlier "Mum's voice was in my soul," (383) Dad's lilting voice and his lyrical, charismatic and storytelling skills are what maintains Azaro's connection with the world of the living: "he sang wonderful tunes into my ears. He told me stories in songs about our ancestors" (389). Dad's and Mum's voices might therefore be the ones that eventually manage to emerge and dominate in The Famished

7. Another approximation of the device of the Greek chorus is to be found when people from the crowd watch Dad exercise and comment on the way he is thus neglecting his wife and son (419-20). These anonymous members of the throng speak in rhyming stichomythia marked by symmetrical syntactical constructions, anaphoras and a rhythmic regularity, which demonstrate a poetic and proverbial dimension. 
Road, the ones that connect with the voices of the past, of tradition, of ancestors, through the heritage of storytellers.

The voice of the storyteller is particularly powerful in a novel that draws from the rich West African oral tradition of narratives, myths and folklore tales, told by the griot who holds an important social role in the community as a vehicle of cohesion and a preserver of local culture. According to Okri, storytellers are "the living memory of a people $[\ldots]$ the living libraries, the keepers of legends and lore" ( $A$ Way 37). In The Famished Road, Mum and Dad are great storytellers, singing songs about ancestors, telling myths, tales of origins, legends, stories and proverbs. Expressions such as "tell me a story," (94, 298, 305) “Tell us a story" (552) or "I will tell you a story," (361) point to the special bond that exists between teller and audience. Mum and Dad also reassuringly abide by the conventions of traditional fairy tales when they start their stories with "Once upon a time ..." (95), "Once upon a time, Dad began suddenly, [...]" (298). In these two cases, the pause marked by the dots and the interpolated clause gives both Azaro and the reader enough time to adopt the appropriate state of mind (suspend their disbelief, for instance) to listen to or read the stories.

Dad's stories, songs and speeches testify to the importance of orature in African tradition, a term coined by Ugandan linguist and literary theorist Pio Zirimu to refer to "the use of utterance as an aesthetic means of expression" (qtd. in Ngũgĩ wa Thiong'o 111). In such cases, as Ngũgĩ wa Thiong'o explains, "there is no mediation by the written sign. The production line runs from orality straight to aurality: the mouth produces, the ear consumes directly" (Ngũgĩ wa Thiong'o 105). In the first novel in the Yoruba language, Daniel Olorunfemi Fagunwa's The Forest of a Thousand Daemons: A Hunter's Saga (1938), translated into English by the Nobel prize winner Wole Soyinka in 1968, the hunter Akara-ogun tells an ever-growing audience the story of his supernatural encounters with demons, fantastic creatures, spirits and gods, turning his storytelling into a form of performance. In The Famished Road, Dad's speeches but also the rapidlypaced dialogues analysed above and the numerous instances of storytelling all take on the characteristics of orality based on such devices as repetitions, sound echoes and rocking rhythms. In all cases, however, the passage from the oral form to the written word transforms the medium by silencing the original voice.

In his study on oral poetry, Paul Zumthor defines writing as "language without voice" (4) and adds that live voice is "in exile in writing" (127). Voice in writing is certainly not literally sonorous and partakes of the simulacrum, even though, in some cases, it seems to imitate the orality of speech. This written voice which is read rather than heard can never be more than an "effect of voice," (Rabaté 4) a fiction, an illusion, a spectre, a metaphor, for the voice cannot be presented, but only represented. To quote Jean-Pierre Martin, the voice in a text is "the name of a phantasm, the trace of an impossible incarnation, the trail of an evanescent presence [...]. It can only be a vocal representation" (29). Pascal Quignard explains for his part that the modern writer is a "phonoclast" as well as a "logoclast," someone who "smashes the voice and the oral circle," who no longer transcribes speech but thoughts which have become quiet and have "left behind all the transitive and corporal art of the voice" (Gêne 34-5). According to Quignard, writing and reading are essentially silent activities and, as such, mechanisms of devocalisation: "The book is a piece of silence in the hands of the reader" (Petits 87). One could argue however that reading actually consists in listening to the 
voice of the text, to its resonance, from the very silence of the page, and a successful book such as The Famished Road is one that manages to make voices heard or at least to create the illusion of voice in all its variations and tonalities.

The musical metaphor with issues of rhythm and meter, intonation and accent, is conventional enough in literary criticism, and books are sometimes compared to scores on which each object would symbolise a note, each scene a musical piece, each pause a silence, and the text as a whole could be conceived as a symphony, complete with concords and discords. The reader is thus encouraged to listen to the text, to read with his ears. It seems therefore necessary to challenge the common opposition between the presence and vivacity of the live voice and the supposed absence of voice in a written text. What is necessary is perhaps to differentiate the live voice, speech, the spoken (which belong to the oral domain) and orality, i.e., a voice in writing which is not a simple transcription of an oral code into a written one, but a specific type of voice which can be heard in the deepest recesses of the text. Writers can therefore give the reader a sense of texture, grain and timbre, and let them perceive diverse tonalities, inflexions and accents. The voice is still soundless and an "effect of voice," but it is so finely chiselled that "the reader hears what he sees" (Goux 182).

In The Famished Road, Dad's "stories in songs" (389) and his moving declaration of love to his son told during the latter's hunger strike are marked by such a musical and poetic sense enhanced by anaphoras, alliterations, assonances and a lulling rhythm. Apart from very few additions, one of Dad's melodies (388-9) is the prose version of Okri's poem "An African Elegy." As Dad sings his love for his son, the lexical field of music prevails, duplicating the sound effects of the speech itself: "The stars are playing on a flute. The air is sweet with the music of an invisible genius. Love is crying in my flesh, singing strange songs" (386); "The water-maiden sings for us"; "Our life appears to be a sad music" (387); sorrow is "the mother of music" and "our music is sweet" (388); "The ocean is full of songs" (389). Poetic images blur the boundaries between worlds and natural elements - "I drank the moon tonight," "The rain is full of flowers" (386) - and turn Dad's ballad into a hopeful elegy to his dying son.

At the end of the novel, Dad's speech announcing a new age (571-2) takes on homiletic, shamanic, utopian, visionary and prophetic undertones, which may also be heard in Okri's own poetry and in some of his essays and interviews. Dad's mesmerising speech is based on rhetorical devices meant to convey a warning as well as a message of hope for the future through short, simple and stable sentences, repetitions and anaphoras, and the use of the first person plural pronoun that involves the ethical responsibility and commitment of the whole community. Such paratactic sentences as "Our lives are changing. Our gods are silent. Our ancestors are silent," (571) are based on a regular rhythm, simple vocabulary and repetitions that are meant to emphasise powerful ideas and let the listener ponder on them. Dad's speech is characterised by a series of paratactic assertions that sound like riddles and challenge our hermeneutic skills while at the same time appealing to our musical sense. Sentences such as "The heart is bigger than a mountain. One human life is deeper than the ocean" or "The sky is inside us. The earth is in us" (572) encourage the reader both to meditate on the value of human life and man's connection with the universe, and to be alert to the melodious qualities of Okri's

8. The poem and the passage in the novel start with "We are the miracles that God made" and end with "Destiny is our friend" (388-9). 
poetic prose. Dad seems here to have taken on the role of shaman, town crier, spokesman, griot and charismatic leader, all functions that rely on honed vocal skills. Dad's musical voice espouses the ebb and flow of syntax and the reader can get carried away by the euphonic flow of words. After he has finished talking, Azaro remarks: "There was a long silence as we swam around in the strange currents of Dad's words" (573).

In A Midsummer Night's Dream, Bottom, playing the role of Pyramus, has recourse to synaesthesia when he claims: "I see a voice" $(\mathrm{V}, 1,189)$. This might very well reflect the experience of the reader of The Famished Road who can see voices on the page but cannot hear them literally. However, Okri's acute attentiveness to the fluctuations and tonalities of human, natural and supernatural voices transform his silent piece of written literature into the vivid simulacrum of a symphony. Just as Azaro oscillates between the mundane world and the esoteric realm, the reader is aware of the echoes and silences of collective and individual voices, and to the euphony and fluidity of Okri's poetic prose. Okri said in an interview that because Africa is "full of presences," he was trying to orchestrate in his novel "a rich opera of presences" and render textually the "multidimensionality of reality” (Guignery Homelands, 22). In his polyphonic novel, Ben Okri (who is himself endowed with a charismatic voice, as evidenced in his readings and interviews) has managed to mix the Western literary tradition of the classical Greek chorus with the modes of West African oral folktales in a way that challenges the supposed limitation of the written word and allows voices to resonate. As a character in J. M. Coetzee's Foe exclaims, "[w]riting is not doomed to be the shadow of speech" (142).

Vanessa GuIGNERY

École Normale Supérieure de Lyon, Institut Universitaire de France

\section{Works Cited}

Becketт, Samuel. The Complete Dramatic Works. 1986. London: Faber and Faber, 2006.

Coetzee, J. M. Foe. 1986. London: Penguin, 1987.

Danielewsiki, Mark Z. House of Leaves. New York: Pantheon Books, 2000.

Deandrea, Pietro. "An Interview with Ben Okri." Africa America Asia Australia 16 (1994): 55-82.

Elze-Volland, Jens Frederic. "Precarity and Picaresque in Contemporary Nigerian Prose: An Exemplary Reading of Ben Okri's The Famished Road." Negotiating Afropolitanism: Essays on Borders and Spaces in Contemporary African Literature and Folklore. Ed. Jennifer WAwRZINEK and J.K.S. MAKOKHA. Amsterdam: Rodopi, 2011. 47-58.

Goux, Jean-Paul. La Fabrique du continu. Essai sur la prose. Seyssel: Champ Vallon, 1999.

Guignery, Vanessa. Seeing and Being: Ben Okri's The Famished Road. Paris: PU de France, 2012.

—. ed. The Famished Road: Ben Okri's Imaginary Homelands. Newcastle-upon-Tyne: Cambridge Scholars Publishing, 2013.

MARTin, Jean-Pierre. La Bande sonore. Paris: José Corti, 1998.

NGŨGĩ Wa Thiong'o. Penpoints, Gunpoints and Dreams. Towards a Critical Theory of the Arts and the State in Africa. 1998. Oxford: Oxford UP, 2003.

Okri, Ben. The Famished Road. 1991. London: Vintage, 2003.

—. "An African Elegy." An African Elegy. London: Jonathan Cape, 1992. 41.

—. A Way of Being Free. London: Phoenix House, 1997.

—. Infinite Riches. 1998. London: Phoenix House, 1999.

QuaYson, Ato. Strategic Transformations in Nigerian Writing. Oxford: James Currey, 1997.

Quignard, Pascal. Une Gêne technique à l'égard des fragments. Montpellier: éditions fata morgana, 1986.

-. Petits traités. 1990. Vol. 1. Paris: Gallimard, 1999.

Rabaté, Dominique. Poétiques de la voix. Paris: Jean Corti, 1999.

Shakespeare, William. A Midsummer Night's Dream. 1600. London: Penguin, 1967.

—. The Tempest. 1623. Oxford: Oxford UP, 1998. 
Stenhouse, Davis. “It Came to Him Like a Dream.” Sunday Times 19 August 2007: 7.

Warnes, Christopher. Magical Realism and the Postcolonial Novel: Between Faith and Irreverence. Basingstoke: Palgrave Macmillan, 2009.

Zumthor, Paul. Oral Poetry: an Introduction. 1983. Trans. Kathryn Murphy-Judy. Minneapolis: U of Minnesota P, 1990. 